\title{
Determination of glycosidase activity in porcine oviductal fluid at the different phases of the estrous cycle
}

\author{
Luis César Carrasco ${ }^{1,2}$, Raquel Romar ${ }^{1}$, Manuel Avilés ${ }^{3}$, Joaquín Gadea ${ }^{1}$ and Pilar Coy ${ }^{1}$ \\ ${ }^{1}$ Department of Physiology, Faculty of Veterinary Science, University of Murcia, 30071 Murcia, Spain, ${ }^{2}$ Department \\ of Biology, Faculty of Basic Sciences, University of Pamplona, 2-102 El Carmen, Santander del Norte, Pamplona, \\ Colombia and ${ }^{3}$ Department of Cell Biology and Histology, Faculty of Medicine, University of Murcia,
} 30071 Murcia, Spain

Correspondence should be addressed to R Romar; Email: rromar@um.es

\begin{abstract}
Sperm-oocyte binding and gamete-oviductal epithelium interactions are carbohydrate-mediated events occurring in the oviductal fluid (OF). Thus, knowledge about the activities of glycosidases (enzymes catalyzing hydrolytic cleavage of terminal sugar residues) in this milieu would help us understand the molecular mechanisms involved in these events. This work was carried out to investigate the glycosidase activity, protein content, and volume of OF collected from gilts and sows. Oviducts were classified into four phases of the estrous cycle (early follicular, late follicular, early luteal, and late luteal) based on the appearance of the ovaries. OF was aspirated, centrifuged, measured for volume, and frozen until assay. Substrates conjugated to 4-methylumbelliferyl were used to screen the activities of seven different glycosidases at physiological pH (7.2). $\alpha$-L-Fucosidase and $\beta$ - $N$-acetyl-glucosaminidase activities increased at the late follicular phase to decrease after ovulation. $\beta$-D-Galactosidase, $\alpha$-D-mannosidase, and $\beta$ - $N$-acetyl-galactosaminidase showed higher activities at the early follicular phase, which decreased after ovulation. $N$-Acetyl-neuraminidase and $\alpha$-D-galactosidase did not show activity at any phase of estrous cycle neither in sows nor in gilts at $\mathrm{pH} \mathrm{7.2,} \mathrm{although} \mathrm{it} \mathrm{did} \mathrm{at} \mathrm{acidic} \mathrm{pH}(4.4)$ in the follicular and luteal phase samples. Total protein also changed during the cycle showing the maximum secretion at the late follicular phase $(2118.6 \pm 200.7 \mu \mathrm{g} /$ oviduct). The highest volumes of $O F$ were collected from the oviducts at the late follicular phase $(50.7 \pm 1.3 \mu \mathrm{l} /$ oviduct). These results indicate that $\mathrm{OF}$ from sows and gilts shows glycosidase activity varying throughout the estrous cycle suggesting a role of these enzymes in carbohydrate-mediated events.

Reproduction (2008) 136 833-842
\end{abstract}

\section{Introduction}

Sperm-egg interactions in numerous species including mammals are mediated by protein receptors on the sperm plasma membrane attaching to carbohydratecontaining molecules on the surface (i.e., zona pellucida) of oocytes reviewed by Benoff (1997). Binding of boar sperm to epithelial cells in the oviduct is a selective carbohydrate-mediated process (Talbot et al. 2003, Rath et al. 2006, Taylor et al. 2008). All these events take place in the oviduct where appropriate enzymes may change the structure of the interacting oligosaccharides. Glycosidases are enzymes, usually contained in the lysosomes that catalyze hydrolytic cleavage of terminal sugar residues from the glycan portion of glycoproteins and glycolipids. Although it was expected for glycosidases to be functional only in acidic environments, Tulsiani et al. (1995) demonstrated that this is not always the case. As an example, $\beta$-galactosidase optimally cleaves the synthetic substrate at acidic $\mathrm{pH}$, but it shows maximum activity toward glycoprotein substrates in a neutral environment. This may explain how the $\beta$-galactosidase or perhaps other 'acidic' glycosidases could be functional in the different extracellular sites where they have been detected, such as blood (Tulsiani \& Touster 1981), sperm membranes (Tulsiani et al. 1989, Cornwall et al. 1991), epididymal luminal fluid (Skudlarek et al. 1993), and fluids from the female reproductive tract (Roberts et al. 1975, 1976, Tulsiani et al. 1996).

Oviductal fluid (OF) is the physiological milieu where fertilization occurs. However, precise studies about glycosidase activity in the OF during the estrous cycle in mammalian species such as the pig or cow, where reproductive technologies are usually and widely performed, are scarce (Roberts et al. 1975, 1976, Tulsiani et al. 1996). On the contrary, studies on several glycosidase activities in sperm membranes (Tulsiani et al. 1989, Cornwall et al. 1991) and epididymal fluid (Skudlarek et al. 1993) are available.

Although most glycosidases are most active at acidic $\mathrm{pH}$ (Tulsiani et al. 1995), they can show activity at higher $\mathrm{pH}$. The $\mathrm{pH}$ profile in the pig oviduct is not static, but differs considerably with region of the oviduct and with 
stage of cycle (Nichol et al. 1997). In cannulated animals, it was 7.9 (Engle et al. 1968) and 8.1 just before ovulation on the second day of estrus (Hunter 1988). A wider study showed that fluid collected from the ampullae of cannulated animals was 7.9 and 7.3 in preovulatory and postovulatory phases (Nichol et al. 1997) respectively, and we have observed that porcine fluid obtained after oviduct aspiration is around 6.6-7.3 (unpublished data). Therefore, the presence of active glycosidases at a neutral $\mathrm{pH}$ in the $\mathrm{OF}$ could have potential roles in different events related to sperm reservoir formation, sperm capacitation, final oocyte maturation, gamete interaction, and early embryo development. It has already been proposed that glycosidases could be involved in the control of polyspermy (Miller et al. 1993, Velasquez et al. 2007), sperm-oviductal epithelial cells interaction (Lefebvre et al. 1997), sperm-zona pellucida binding (Miller et al. 1993, Matsumoto et al. 2002, Venditti et al. 2007), sperm capacitation (Taitzoglou et al. 2007), or dispersion of cumulus cells (Takada et al. 1994). All these events take place in the oviduct and have been the aim of studies to increase our knowledge about the molecular basis of reproductive functions, but, surprisingly, we lack of precise studies about the activities of the different glycosidases in the OF. The exception could be found in some early reports from Roberts et al. (1975, 1976) showing low activities for $\alpha$-L-fucosidase, $\beta$-D-fucosidase, $\alpha$-D-galactosidase, $\beta$-D-galactosidase, $\alpha$-D-glucosidase, $\beta$-D-glucosidase, $\beta$ - $N$-acetyl-galactosaminidase, $\beta$ - $N$-acetyl-glucosaminidase, $\alpha$-D-mannosidase, and $\beta$-D-mannosidase in the OF from cattle and sheep, with a significant increase during diestrus and pregnancy for the activities of $\beta$ - $N$-acetyl-galactosaminidase and $\beta$ - $N$-acetyl-glucosaminidase. Apart from these studies, performed at acidic $\mathrm{pH}$, there is no further available information.

The main objective of the present study was to determine the activities of seven exoglycosidases, whose roles in different reproductive events have been speculatively proposed, in the OF of gilts and sows at the follicular or luteal phase of the estrous cycle. The assayed glycosidases were $\alpha$-L-fucosidase, $\beta-N$-acetylglucosaminidase, $\beta$-D-galactosidase, $\alpha$-D-mannosidase, $\beta$ - $N$-acetyl-galactosaminidase, $\alpha$-D-galactosidase, and $\mathrm{N}$-acetyl-neuraminidase.

\section{Results \\ Glycosidase activity}

Sow and gilt OF displayed $\alpha$-L-fucosidase, $\beta$ - $N$-acetylglucosaminidase, $\beta$-D-galactosidase, $\alpha$-D-mannosidase, and $\beta$ - $N$-acetyl-galactosaminidase activities at all phases of the cycle when assessed at $\mathrm{pH}$ 7.2. OF from sows showed statistical differences among follicular and luteal phases for $\alpha$-L-fucosidase ( $P<0.01$; Fig. $1 \mathrm{~A})$, $\beta$ - $N$-acetyl-glucosaminidase ( $P<0.01$; Fig. 1B), $\beta$-D-galactosidase $(P<0.01$; Fig. $1 \mathrm{C}), \alpha$-D-mannosidase $(P<0.01$; Fig. 1D), and $\beta$ - $N$-acetyl-galactosaminidase $(P<0.01$; Fig. 1E) activities. The significances were maintained when the data were transformed into specific enzymatic activity (SEA; Fig. 1). Some patterns could be observed in the activity of the enzymes. On the one hand, $\alpha$-L-fucosidase and $\beta$ - $N$-acetyl-glucosaminidase showed maximum activity at the late follicular phase (28.4 and $36.2 \mathrm{U}$ respectively) with a decrease of $50 \%$ in the activity after ovulation and then steadily increased their activity at the late luteal and early follicular phases. On the other hand, $\beta$-D-galactosidase, $\alpha$-D-mannosidase, and $\beta$ - $N$ acetyl-galactosaminidase showed higher activity at the early follicular phase (34.3, 51.0, and $34.1 \mathrm{U}$ respectively) decreasing $65-70 \%$ of their activity close to ovulation and maintaining these low levels during the luteal phase.

Glycosidase activity at pH 7.2 in OF from gilts at the early follicular phase is shown in Fig. 2. Comparison between EA of OF from sows and gilts at the same cycle phase (early follicular phase) is shown in Fig. 3. Comparison of EA did not reach statistical significance but $\alpha$-L-fucosidase had a tendency to be more active in OF from gilts $(P=0.06)$. When SEA data were compared, it was observed that $\beta$-Dgalactosidase had a higher activity in OF from sows $(P=0.04)$ being the SEA of the remaining glycosidases similar between prepubertal and pubertal animals.

All fluorescence data (arbitrary fluorescence units) obtained for $\alpha$-L-fucosidase, $\beta$-D-glucosaminidase, $\beta$-Dgalactosidase, $\alpha$-D-mannosidase, and $\beta$-D-galactosaminidase were higher in the OF than in the positive controls run in human seminal plasma (data not shown).

Neither OF from sows nor from gilts showed $\alpha$-Dgalactosidase or $\mathrm{N}$-acetyl-neuraminidase activity in any sample at any phase of the estrous cycle at pH 7.2. Positive controls reached 26453 and 13438 fluorescence units for $\alpha$-D-galactosidase and $N$-acetyl-neuraminidase respectively. However, both enzymes showed activity at $\mathrm{pH}$ 4.4. EA of $\alpha$-D-galactosidase was $97.27 \pm 34.79$ and $116.20 \pm 68.09 \mathrm{U}$ respectively for follicular and luteal phases. Neuraminidase reached a discrete activity with $4.48 \pm 1.60$ and $5.36 \pm 3.14 \mathrm{U}$ respectively for follicular and luteal phases.

\section{Protein content and volume of $\mathrm{OF}$}

Concentration of protein $(\mu \mathrm{g} / \mu \mathrm{l}$ OF) in OF from sows is shown in Table 1. A lower concentration of protein was observed at the late follicular phase. However, the volume of OF reached its maximum at the late follicular phase $(50.7 \mu \mathrm{l} /$ oviduct; Table 1$)$ to decrease progressively after ovulation (early luteal phase). Therefore, when the total amount of protein ( $\mu \mathrm{g} / \mathrm{oviduct}$ ) was calculated, significant differences were found with the highest secretion of protein close to the moment of ovulation (2118.6 $\pm 200.7 \mu \mathrm{g} /$ oviduct) decreasing at the early luteal phase (after ovulation). 

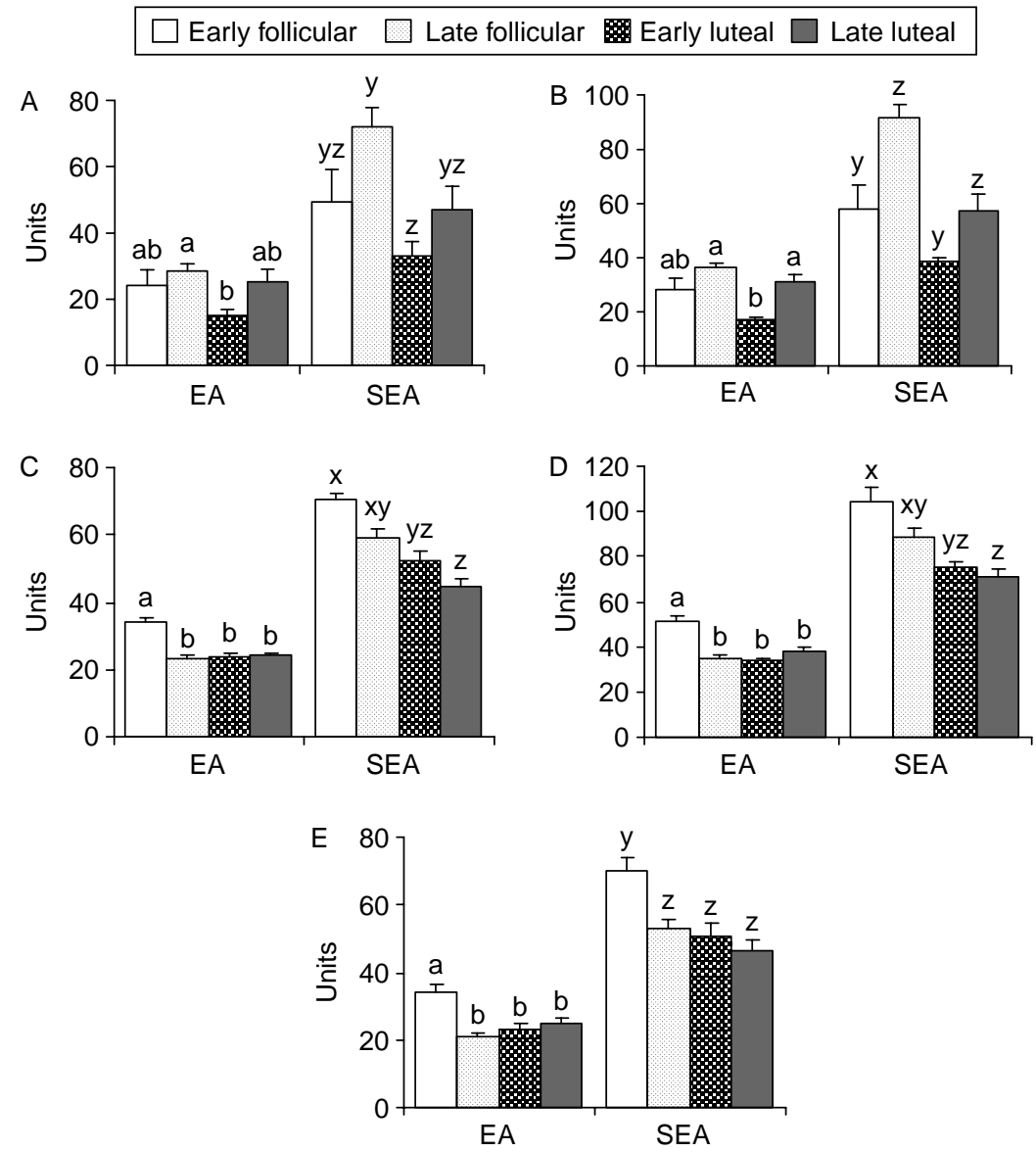

Data from OF from gilts are presented in Table 2. Comparison of the total amount of protein ( $\mu \mathrm{g} / \mathrm{oviduct}$ ) between prepubertal and pubertal animals at the early follicular phase did not show any difference.

\section{Discussion}

Oviduct-sperm interaction and fertilization in mammals are carbohydrate-mediated processes that take place in the oviduct (reviewed by Talbot et al. (2003)). It is obvious then to suppose that oviductal glycosidases, if present and active at a physiological $\mathrm{pH}$, may have a role in fertilization, as has been reported for other glycosidases in sperm membranes (Tulsiani et al. 1989, Cornwall et al. 1991) or epididymal fluid (Skudlarek et al. 1993). However, and surprisingly, no studies about enzymatic composition in such an important biological fluid as the OF have been carried out in mammals, except some old studies in cows and sheep (Roberts et al. 1975, 1976) or more recently in the hamster (Tulsiani et al. 1996). The results from this study show detailed and novel data about the glycosidase activity at physiological $\mathrm{pH}$ and protein concentration in the
Figure 1 Units for enzymatic activity (EA) and specific enzymatic activity (SEA) for several glycosidases assessed at $\mathrm{pH} 7.2$ in oviductal fluid collected from sows at different stages of the estrous cycle. (A) $\alpha$-L-fucosidase, (B) $\beta$ - $N$-acetyl-glucosaminidase, (C) $\beta$-D-galactosidase, (D) $\alpha$-D-mannosidase and (E) $\mathrm{N}$-acetyl-galactosaminidase. Different letters in each enzyme and in the same activity denote statistical significance $(P<0.01)$. porcine OF. Due to the lack of previous reports demonstrating such an activity and the lack of knowledge about the specific molecules involved in the porcine gametes interaction, all our interpretations for their presence in this milieu are only speculative.

Porcine OF from gilts and sows showed $\alpha$-Lfucosidase, $\beta$ - $N$-acetyl-glucosaminidase, $\beta$-D-galactosidase, $\alpha$-D-mannosidase, and $\beta$ - $N$-acetyl-galactosaminidase activities when assessed at neutral $\mathrm{pH}$ with variations during the estrous cycle. All these glycosidases showed maximum activity at the follicular phase, decreasing after ovulation. We have to bear in mind that in our study fluid from whole oviducts was pooled. It has been shown that the $\mathrm{pH}$ profile in the pig oviduct is not static and differs considerably with region of the oviduct and stage of cycle (Nichol et al. 1997), so in vivo oviductal EA could be slightly different in the specific regions of the oviduct. Given that glycosidases are glycoproteins, and the oviductal protein secretion is importantly regulated by ovarian steroids, mainly estrogen (Buhi et al. 2000), it could be inferred that the changes in glycosidase activity during the estrous cycle might be hormonally regulated. 


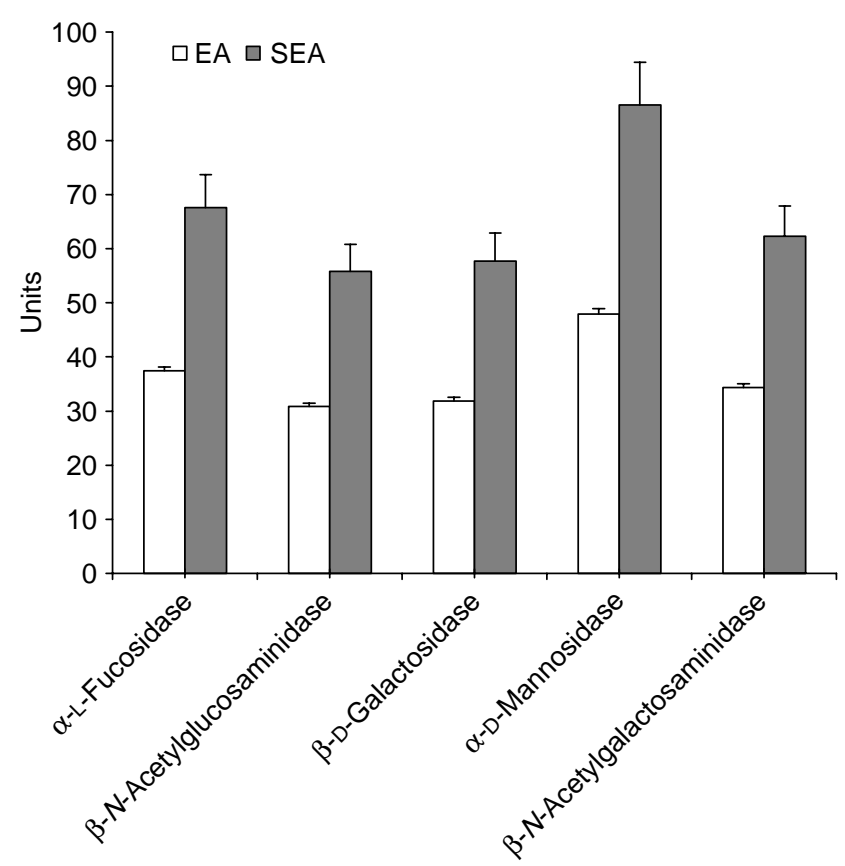

Figure 2 Units of enzymatic activity (EA) and specific enzymatic activity (SEA) for several glycosidases assessed at neutral $\mathrm{pH}$ in porcine oviductal fluid collected from gilts at early follicular phase.

In this study, we show that porcine OF has $\alpha$-Lfucosidase activity that is coincident with previous studies in hamster OF (Tulsiani et al. 1996). In pigs, experiments with lectins show that carbohydrates are differently expressed among regions of the oviduct during the different phases of the estrous cycle (Raychoudhury et al. 1993, Walter \& Bavdek 1997, Sant'ana et al. 2005). Lotus tetragonolobus lectin mainly recognizes $\alpha$-L-fucose residues, and during the follicular phase its binding sites are only present on epithelial cells of the isthmic segment, the ampulla and infundibulum being unreactive (Walter \& Bavdek 1997). Besides, there is evidence for a fucose-binding protein in boar (Topfer-Petersen et al. 1985) and, also, bovine (Ignotz et al. 2007) spermatozoa. In theory, the release of spermatozoa from the sperm reservoir could either be a consequence of a loss of binding sites or due to alterations in the spermatozoa themselves (reviewed by Rodriguez-Martinez (2007)). Thus, the active oviductal $\alpha$-L-fucosidase could remove the $\alpha$-L-fucose residues and likely take part in sperm release from the oviduct since it is known that the isthmus is the functional sperm reservoir in pigs (Hunter 2005). Other mechanisms already described that such activation of sperm motility by sperm bicarbonate uptake might also contribute to this release, together with $\alpha$-L-fucosidase (Brandt et al. 2006). This hypothesis needs to be confirmed but it is supported by our observation of maximum $\alpha$-L-fucosidase activity close to the moment of ovulation.

According to our results, OF shows hexosaminidase activity $(\beta-N$-acetyl-glucosaminidase and $\beta$ - $N$-acetyl-
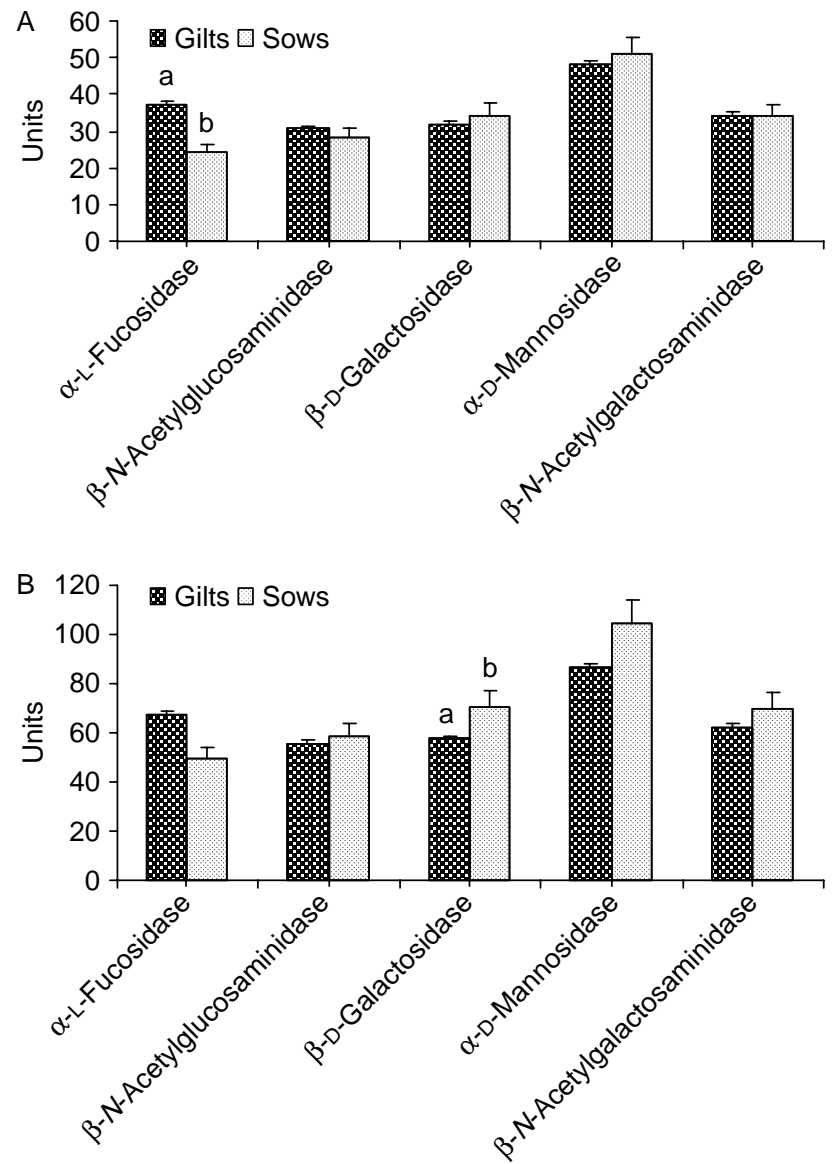

Figure 3 Comparison of enzymatic activity for several glycosidases assessed at $\mathrm{pH} 7.2$ in oviductal fluid collected from sows and gilts at early follicular phase. (A) Units of enzymatic activity (EA). Different letters in each enzyme and in the same activity denote statistical significance $(P=0.06)$. (B) Units of specific enzymatic activity (SEA). Different letters in each enzyme and in the same activity denote statistical differences $(P<0.05)$.

galactosaminidase). $\quad \beta$ - $N$-Acetyl-glucosaminidase activity has been already described in the oviduct from other species (Roberts et al. 1975, 1976, Tulsiani et al. 1996, Droba et al. 2005), and in our study the highest activity was at the late follicular phase. Regarding oviductal $\beta$ - $N$-acetyl-galactosaminidase activity, no studies are available and we observed its maximum activity at the early follicular phase. These results are in concordance with lectin studies in the porcine oviduct. On the one hand, it has been shown that Triticum vulgaris, specific against $\mathrm{D}-\mathrm{N}$-acetyl-glucosamine sugar residues, reacts strongly with the oviduct epithelium during the follicular phase (Walter \& Bavdek 1997). On the other hand, studies with Helix pomatia (Walter \& Bavdek 1997) and Dolichos biflorus lectins, which recognize $\alpha$-GalNAc residues, have shown that the porcine oviduct expresses this sugar especially during the follicular phase. Therefore, oviductal hexosaminidase might have a role in remodeling the oviduct 
Table 1 Protein content, volume, and total amount of protein in oviductal fluid from sows at different phases of estrous cycle.

\begin{tabular}{llll}
\hline OF from sows & Protein $(\mu \mathrm{g} / \mu \mathrm{l}$ OF) & Volume $(\mu$ l OF/oviduct $)$ & Total protein $(\mu \mathrm{g} / \mathrm{oviduct})$ \\
\hline Early follicular & $48.9 \pm 3.6^{\mathrm{a}, \mathrm{b}}(\mathrm{Ns}=25)$ & $27.9 \pm 0.3^{\mathrm{a}}(\mathrm{No}=49)$ & $1354.8 \pm 172.8^{\mathrm{a}}$ \\
Late follicular & $39.5 \pm 1.4^{\mathrm{a}}(\mathrm{Ns}=57)$ & $50.7 \pm 1.3^{\mathrm{b}}(\mathrm{No}=48)$ & $2118.6 \pm 200.7^{\mathrm{b}}$ \\
Early luteal & $45.3 \pm 2.5^{\mathrm{a}, \mathrm{b}}(\mathrm{Ns}=53)$ & $40.2 \pm 1.3^{\mathrm{a}}(\mathrm{No}=60)$ & $1680.5 \pm 122.8^{\mathrm{a}}$ \\
Late luteal & $53.6 \pm 4.0^{\mathrm{b}}(\mathrm{Ns}=33)$ & $30.0 \pm 0.5^{\mathrm{a}}(\mathrm{No}=69)$ & $1563.2 \pm 149.8^{\mathrm{a}}$ \\
$P$ value & $<0.01$ & $<0.01$ & 0.02 \\
\hline
\end{tabular}

${ }^{\mathrm{a}, \mathrm{b}}$ Different letters in the same column represent statistically significant differences. Ns, number of samples analyzed; No, number of oviducts aspirated.

surface, thus affecting gamete interactions with oviductal cells. Although specific GlcNAc and GalNAc lectins in boar sperm have not been described yet, a lectin binding GalNAc in rat spermatozoa has been described (Abdullah \& Kierszenbaum 1989). Another role that could be hypothesized for the oviductal hexosaminidase concerns the dispersion of cumulus cells from ovulated oocytes. This role has been attributed to the boar acrosomal $\beta$-N-acetyl-glucosaminidase that has been proposed to facilitate the passing by sperm through cumulus cells before they bind to the zona pellucida (Takada et al. 1994). However, the acrosomal content of the fertilizing spermatozoa is mainly released after sperm binding to the zona pellucida (ZP), making it difficult for the acrosomal $\beta$ - $N$-acetyl-glucosaminidase to participate in the cumulus dispersion (Fazeli et al. 1997, Topper et al. 1999). We hypothesize that it might be the oviductal $\beta$ - $N$-acetyl-glucosaminidase that is responsible for such an effect. Besides, in our study, maximum activity of oviductal $\beta$-N-acetyl-glucosaminidase was observed around fertilization time. Finally, a last role for the oviductal hexosaminidase might be related to the sperm-oocyte interaction, hydrolyzing the $\beta$-N-acetyl-glucosamine moieties present at the porcine ZP and thus affecting the sperm binding to the zona pellucida.

Porcine OF showed $\beta$-D-galactosidase activity as previously found in OF from several species (Roberts et al. 1975, 1976, Tulsiani et al. 1996, Droba et al. 2005). A feasible role for oviductal $\beta$-D-galactosidase would concern remodeling the ZP since $\beta$-galactosyl residues in the $\mathrm{ZP}$ oligosaccharides are involved in porcine sperm-egg binding (Yonezawa et al. 2005). These authors showed that treatment with $\beta$-D-galactosidase and endo- $\beta$-D-galactosidase of isolated porcine ZPs reduced the number of sperm bound and inhibited the sperm penetration in treated oocytes. These data

Table 2 Protein content, volume, and total amount of protein in oviductal fluid from gilts at the early follicular phase of estrous cycle.

\begin{tabular}{lccc}
\hline OF from gilts & $\begin{array}{c}\text { Protein } \\
(\mu \mathrm{g} / \mu \mathrm{l} \mathrm{OF})\end{array}$ & $\begin{array}{c}\text { Volume } \\
(\mu \mathrm{l} \text { OF/oviduct })\end{array}$ & $\begin{array}{c}\text { Total protein } \\
(\mu \mathrm{g} / \mathrm{oviduct})\end{array}$ \\
\hline Early follicular & $\begin{array}{c}55.3 \pm 4.3 \\
(\mathrm{Ns}=27)\end{array}$ & $\begin{array}{c}23.5 \pm 0.6 \\
(\mathrm{No}=43)\end{array}$ & $1367.8 \pm 86.1$ \\
\hline
\end{tabular}

Ns, number of samples analyzed; No, number of oviducts aspirated. imply that in vivo, $\beta$-D-galactosidase could regulate the sperm binding sites present in the zona pellucida, reducing the sperm that could fertilize the oocyte and consequently reducing polyspermy. This could be one of the reasons for the different rate of polyspermy observed under in vivo and in vitro fertilizations.

In our study, $\alpha$-D-mannosidase activity was maximal during the follicular phase of the cycle, similar to the observations in the rat (Pizarro et al. 1984). Oviductal $\alpha$-Dmannosidase activity has also been described in ruminants and hamster (Roberts et al. 1975, 1976, Tulsiani et al. 1996). The role of oviductal $\alpha$-D-mannosidase might be mainly modulating the sperm-oviduct interaction. Porcine oviduct shows reactivity toward concanavalin A lectin that binds to $\alpha$-D-mannose residues (Walter \& Bavdek 1997), and it is known that mannose acts as a sperm receptor in the porcine oviductal cells (Wagner et al. 2002). Therefore, $\alpha$-mannose residues could be eliminated by oviductal $\alpha$-Dmannosidase, thus regulating the population of sperm attaching to the oviduct. Once attached, their release could be regulated by means of the $\alpha$-mannosidase anchored in the plasma membrane of the boar acrosomal region (Kuno et al. 2000) or even by the oviductal one. Boar spermadhesin AWN-1 is a sperm surface-associated lectin and a major protein of porcine seminal plasma (Calvete et al. 1997). Recent studies have shown that boar spermadhesins AWN and AQN1 are the dominant carbohydrate-binding sperm proteins and AQN1 has been proposed as the molecule involved in the formation of the oviductal sperm reservoir (Ekhlasi-Hundrieser et al. 2005). Binding of boar sperm to oviductal epithelium was inhibited by the addition of AQN1 but not by AWN (Ekhlasi-Hundrieser et al. 2005). AQN1 recognizes both $\alpha$ - and $\beta$-linked galactose as well as Man $\alpha 1-3$ (Man 1 1-6)Man structures. Recently, it has been shown that an oviductal protein, sperm binding glycoprotein, binds to boar sperm and exposes carbohydrate groups that can be later recognized by AQN1 (Pérez et al. 2006), and that AQN3 in porcine sperm apical plasma membrane firmly binds to ZP (van Gestel et al. 2007). Therefore, both oviductal $\alpha$-D-mannosidase and $\beta$-D-galactosidase might remove these residues affecting sperm interaction with oviductal cells and/or ZP binding. In fact, we have observed that both enzymes have its maximum activity at the early follicular phase, but it significantly decreases at the late follicular and luteal phases. This activity decrease 
might help to maintain boar spermatozoa in the isthmus and to create the sperm reservoir, but at the same time their moderate activity might steadily release the sperm facilitating the fertilization of ovulated oocytes, although this hypothesis needs to be confirmed.

$N$-acetyl-neuraminidase and $\alpha$-D-galactosidase did not show activity in the OF from sows or gilts at any stage of the cycle when assessed at neutral $\mathrm{pH}$, but they displayed activity at acidic $\mathrm{pH}$. These results suggest that the role of these enzymes at the fertilization process, if any, might be acting as lectins rather than as catalysts. It has been shown that boar spermadhesin $\mathrm{AWN}-1$ binds to proteins containing $O$-linked $\mathrm{NeuAc} \alpha(2-3 / 6)-\mathrm{Gal} / 3$ (1-3)-GalNAc and NeuAca(2-3/6)-Gal/3(1-4)-GlcNAc sequences in $\mathrm{N}$-linked triantennary structures (Dostalova et al. 1995). Besides, the absence of terminal sialic acid decreased fivefold the binding affinity. Maybe the presence of an active sialidase in the OF would strongly hamper the porcine sperm-ZP interaction. Regarding $\alpha$-D-galactosidase, spermadhesin AWN binds only the galactose residues (Gal $\alpha 1,3 \mathrm{GalNAc}$ and $\mathrm{Gal} \beta 1,3 \mathrm{Gal}-$ $\mathrm{NAc}$ ) and its addition to oviductal epithelium did not affect boar sperm binding (Ekhlasi-Hundrieser et al. 2005). It might be that $\alpha$-D-Gal residues do not function as sperm receptors in the porcine species as in the mouse, where the Gal $\alpha 1,3 \mathrm{Gal}$ oocyte epitopes implicated in sperm adhesion to the ZP3 glycoprotein are not required for fertilization (Thall et al. 1995). This would help to explain the lack of an active oviductal $\alpha$-D-galactosidase at physiological $\mathrm{pH}$, although this hypothesis needs to be confirmed.

Protein content in OF was higher at estrus as was OF volume. In sows, Iritani et al. (1974) described no changes in protein concentration during the estrous cycle. A higher secretion rate of proteins has been described at proestrus and estrus when events such as fertilization and early cleavage stages of embryos occur (Buhi et al. 1989). This would be more in agreement with our results showing a higher total amount of protein at estrus. Regarding the volume of fluid, there are numerous studies indicating that OF secretion increases during the estrus and decrease during the diestrus (Iritani et al. 1974, Wiseman et al. 1992). This is coincident with our results since we obtained the maximum volume of $\mathrm{OF}$ from the oviducts at the late follicular phase and a decrease as the estrous cycle progressed.

In conclusion, we demonstrate that porcine OF from prepubertal and pubertal animals has $\alpha$-L-fucosidase, $\beta$-N-acetyl-glucosaminidase, $\beta$-D-galactosidase, $\alpha$-D-mannosidase, and $\beta$ - $N$-acetyl-galactosaminidase activities with variations during the estrous cycle, but it did not show $N$-acetyl-neuraminidase or $\alpha$-D-galactosidase activity. This suggests a role of the active glycosidases in reproductive events. Further experiments are necessary to find out the specific functions and role in porcine fertilization for each of the active enzymes.

\section{Materials and Methods}

Unless otherwise indicated, all chemicals and reagents were purchased from Sigma-Aldrich Química S A (Madrid, Spain).

\section{Oviducts classification and collection of $\mathrm{OF}$}

Genital tracts from gilts and sows (Landrace $\times$ Large White) were obtained at the abattoir and transported to the laboratory on ice. The cyclic stage of animals was assessed once in the laboratory, on the basis of ovarian morphology on both ovaries from the same female. Oviducts from sows were classified as early follicular, late follicular, early luteal, or late luteal phase, according to the criteria defined by Hafez \& Hafez (2000; Table 3; Fig. 4). In the tracts from gilts, only ovaries at the early follicular phase were observed (Fig. 4). Both oviducts coming from the same genital tract were classified as in the same stage of the cycle. Tracts with ovaries not clearly matching these criteria, polycystic, and genitals from pregnant animals were discarded from the study.

Once classified, a total of 43 gilt oviducts and 226 sow oviducts were separated from the tracts and quickly washed once with $0.4 \% \mathrm{v} / \mathrm{v}$ cetrimide (alkyltrimethylammonium bromide) solution and two times with Dulbecco's PBS and transferred to Petri dishes on ice and dissected. Once dissected, the oviducts were not opened lengthwise but the porcine OF from whole oviduct was collected by aspiration with an automatic pipette by introducing the tip into the ampulla for a maximum $200 \mu \mathrm{l}$ volume and making a manual ascendent pressure from the isthmus to the ampulla as described previously (Carrasco et al. 2008). Once aspirated, the OF was centrifuged at $7000 \mathrm{~g}$ for $10 \mathrm{~min}$ at $4{ }^{\circ} \mathrm{C}$ to remove cellular debris. Then the supernatant was immediately stored at $-80^{\circ} \mathrm{C}$ until use for glycosidase and protein determinations. After centrifugation, the number of oviducts dissected and OF volume obtained per sample were recorded. Because preliminary experiments showed variations in EA, all samples were analyzed within 2 weeks of freezing.

\section{Assays for glycosidases}

Seven glycosidases were assayed at $\mathrm{pH} 7.2$ in each sample: $N$-acetyl-neuraminidase (EC 3.2.1.18), $\alpha$-D-galactosidase (EC 3.2.1.22), $\alpha$-L-fucosidase (EC 3.2.1.51), $\beta$ - $N$-acetyl-glucosaminidase (EC 3.2.1.52), $\beta$-D-galactosidase (EC 3.2.1.23), $\alpha$-Dmannosidase (EC 3.2.1.24), and $\beta$ - $N$-acetyl-galactosaminidase (EC 3.2.1.53). Glycosidase activities were assayed, as we have previously described (Aviles et al. 1996, Abascal et al. 1998), using 4-methylumbelliferyl-glucopyranosides as substrates. Briefly, stock solutions for substrates $(0.1 \mathrm{M})$ were prepared in purified water and kept at $-80^{\circ} \mathrm{C}$ until use. The day of the assay, OF samples were thawed and working solutions for all substrates prepared $(1 \mathrm{mM})$ by dilution in assay buffer $(\mathrm{pH} 7.2 ; 137.1 \mathrm{mM}$ $\mathrm{NaCl}, 2.7 \mathrm{mM} \mathrm{KCl}, 8.4 \mathrm{mM} \mathrm{Na} \mathrm{HPO}_{4}, 1.46 \mathrm{mM} \mathrm{KH_{2 }} \mathrm{PO}_{4}$, $0.32 \mathrm{mM}$ Na pyruvate, $11.0 \mathrm{mM}$ glucose, and $0.007 \mathrm{~g} / \mathrm{l}$ kanamycin). In an ice bath, $40 \mu \mathrm{l}$ assay buffer, $20 \mu \mathrm{l}$ working solution substrate, and $10 \mu \mathrm{l}$ OF were added in a microtube. Duplicates were prepared for each OF sample. The blank in each sample consisted of $60 \mu \mathrm{l}$ assay buffer and $10 \mu \mathrm{l}$ OF. Substrate blanks for each enzyme were prepared with $50 \mu \mathrm{l}$ assay buffer and $20 \mu \mathrm{l}$ 
Table 3 Classification of porcine oviducts according to ovarian morphology.

\begin{tabular}{|c|c|c|}
\hline & Estrous cycle phase & Ovary morphology \\
\hline Gilts (prepubertal) & Early follicular & $\begin{array}{l}\text { Growing follicles (2-5 mm diameter); absence of signals from previous } \\
\text { cycles (no } \mathrm{CH}, \mathrm{CL} \text {, or } \mathrm{CA} \text { ) }\end{array}$ \\
\hline \multirow[t]{4}{*}{ Sows (pubertal) } & Early follicular & $\begin{array}{l}\text { Growing follicles ( } 2-5 \mathrm{~mm} \text { diameter), } \mathrm{CL} \text { under regression without } \\
\text { surface vascularization or CA from previous cycle }\end{array}$ \\
\hline & Late follicular & $\begin{array}{l}\text { Periovulatory follicles ( } 8-11 \mathrm{~mm} \text { diameter) or close to ovulate }(>11 \mathrm{~mm} \\
\text { diameter) and CA from previous cycle }\end{array}$ \\
\hline & Early luteal & $\begin{array}{l}\text { Recent } \mathrm{CH} \text { or } \mathrm{CL} \text { very vascularized in the peripheria and purple stigma; } \\
\text { small growing follicles and presence/absence of CA }\end{array}$ \\
\hline & Late luteal & $\begin{array}{l}\text { Developed CL with some surface vascularization or CA from previous } \\
\text { cycle; small growing follicles }(<2 \mathrm{~mm})\end{array}$ \\
\hline
\end{tabular}

$\mathrm{CH}$, corpora hemorrhagic; CL, corpora lutea; CA, corpora albicans. Adapted from Hafez Hafez \& Hafez (2000).

working solution substrate. Human seminal plasma (10 $\mu \mathrm{l})$ was used as a positive control since it has shown activity for $\alpha$-Lfucosidase (Alhadeff et al. 1999), $\beta$-N-acetyl-glucosaminidase (Yoshida et al. 1987), $\beta$-D-galactosidase (Corrales et al. 2002), $\alpha$-D-galactosidase (Spiessens et al. 1998), $\alpha$-D-mannosidase (Corrales et al. 2002), and $\beta$ - $N$-acetyl-galactosaminidase (Kapur \& Gupta 1985). Human seminal plasma was obtained from clinic IVI-Murcia (Murcia, Spain). Semen samples were centrifuged at $500 \mathrm{~g}$ for $10 \mathrm{~min}$ and the supernatant aliquoted and stored at $-80^{\circ} \mathrm{C}$ until assay. The use of the samples in the present investigation was approved by the local ethical committee and consent was obtained from patients. Positive control for $\mathrm{N}$-acetylneuraminidase was made with $10 \mu \mathrm{l}(0.05 \mathrm{IU})$ of the commercial enzyme from Clostridium perfringens (C. welchii) since its presence has not been described in seminal plasma. All positive controls were run at $\mathrm{pH} 7.2$. Incubation of samples, blanks, and controls was for $240 \mathrm{~min}$ at $37^{\circ} \mathrm{C}$ and the reaction was stopped by adding to each microtube $0.5 \mathrm{ml}$ glycine buffer containing

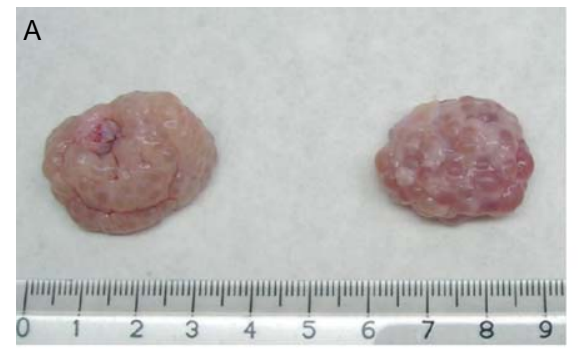

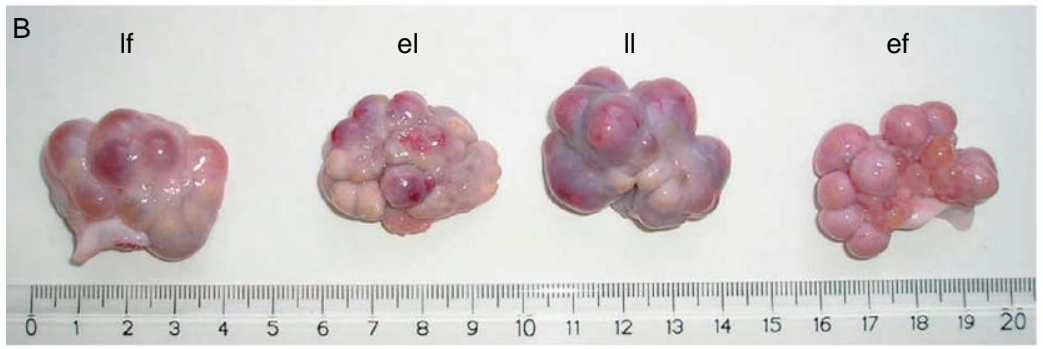
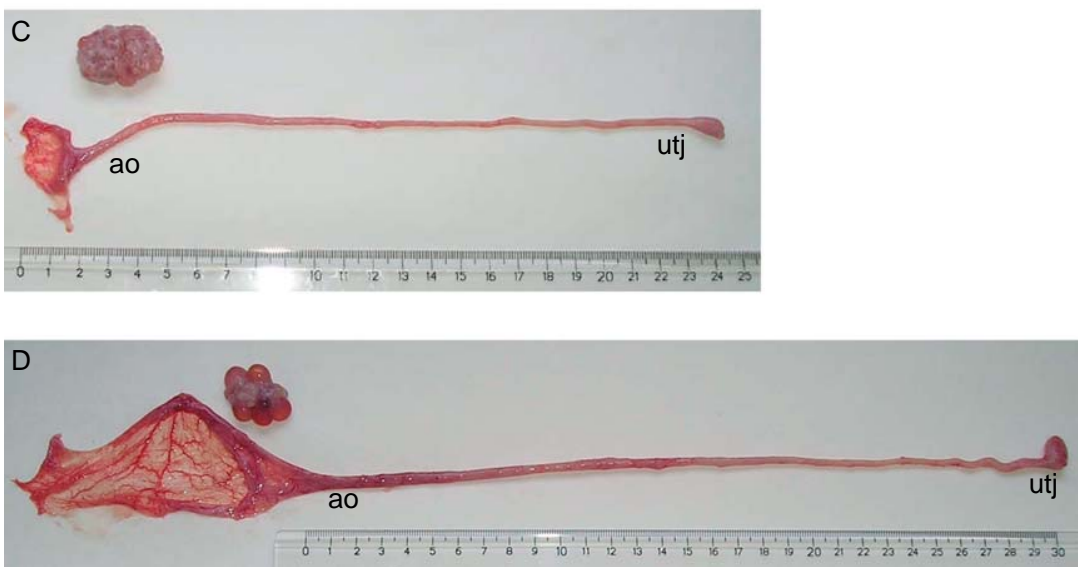

Figure 4 (A) Ovaries from gilts at the early follicular phase. (B) Ovaries from sows at the early follicular (ef), late follicular (If), early luteal (el), and late luteal (II) phases. (C) Dissected oviducts from a gilt at the early follicular phase with its corresponding ovary. (D) Dissected oviduct from a sow at the late follicular phase with its corresponding ovary. oa, oviductal ampulla; utj, utero tubal junction. Scale in $\mathrm{cm}$. 
$0.0085 \mathrm{Mglycine}-\mathrm{CaCO}_{3}$, adjusted to $\mathrm{pH} 10.0$ with $1 \mathrm{M} \mathrm{NaOH}$. Samples, blanks, and controls were run concurrently and fluorescences were read on a spectrofluorimeter (FLUOstar Galaxy; BMG Lab. Technologies, Durham, NC, USA) using wavelengths of 340 and $450 \mathrm{~nm}$ for excitation and emission respectively, and corrected by subtracting both blanks.

Because OF did not show $N$-acetyl-neuraminidase and $\alpha$-Dgalactosidase activities at $\mathrm{pH} 7.2$, a small trial was run to assay these two enzymes at acidic $\mathrm{pH}$. Acidic neuraminidase and $\alpha$-Dgalactosidase of lysosomal origin have an optimum $\mathrm{pH}$ of 4.6-4.8 (Samollow etal. 1990) and 4.4 (Ohshima et al. 1997) respectively. Therefore, the enzymatic assays for samples, blanks, and controls were done, as described previously, but using a sodium acetateacetic acid (0.2 M), adjusted to $\mathrm{pH} 4.4$ as the assay buffer.

One unit $(U)$ of glycosidase activity was defined in all cases as the amount of enzyme necessary to hydrolyze $1 \mathrm{nmol}$ substrate/min at $37{ }^{\circ} \mathrm{C}$ under the above-defined conditions. One unit of glycosidase specific activity was the activity of an enzyme per milligram of total protein.

\section{Protein determination}

Protein concentration in OF samples was determined by the bicinchoninic acid assay (BCA method; Smith et al. 1985; Pierce, Rockford, IL, USA). Following the manufacturer's instructions, incubation of samples with the provided BCA reactive was performed at $37^{\circ} \mathrm{C}$ for $30 \mathrm{~min}$ followed by $15 \mathrm{~min}$ at room temperature and reading of absorbances at $560 \mathrm{~nm}$ on a spectrofluorimeter (FLUOstar Galaxy; BMG Lab. Technologies, Durham, NC, USA). Bovine serum albumin was used as the standard for the protein assays. Three measurements of protein were run in each OF sample with 12, 8, and $4 \mu \mathrm{l}$ OF. Assays for glycosidases and proteins were run in the same OF sample. For each sample, the concentration of protein was the mean among these three measurements. To calculate the SEA, the mean protein value in each phase was used.

\section{Statistical analysis}

Data are presented as the mean \pm s.E.M. The variable EA, SEA, protein concentration, and OF volume were analyzed by oneway ANOVA with cycle stage (follicular versus luteal) or age of animal (gilts versus sows) as a fixed factor. When ANOVA revealed a significant effect, the values were compared by the Tukey test. $P<0.05$ was considered to be statistically significant.

\section{Declaration of interest}

There is no conflict of interest that could be perceived as prejudicing the impartiality of the research reported.

\section{Funding}

This work was supported by the Spanish Ministry of Education and Science and FEDER (grant no. AGL2006-03485) and Murcia Regional Government through Seneca Foundation (grant nos. 03018/PI/05 and 04542/GERM/06).

\section{Acknowledgements}

The authors thank Dr Daulat Tulsiani for the interesting comments and suggestions on the manuscript. We would like to thank the staff of the slaughterhouses Orihuela and El Pozo for supplying the genital tracts, Clinic IVI-Murcia for seminal plasma doses, and Maria Roldan for help with the acidic enzymatic assays.

\section{References}

Abascal I, Skalaban SR, Grimm KM, Aviles M, Martianez-Menarguez JA, Castells MT, Ballesta J \& Alhadeff JA 1998 Alteration of the isoform composition of plasma-membrane-associated rat sperm alpha-L-fucosidase during late epididymal maturation: comparative characterization of the acidic and neutral isoforms. Biochemical Journal 333 201-207.

Abdullah M \& Kierszenbaum AL 1989 Identification of rat testis galactosyl receptor using antibodies to liver asialoglycoprotein receptor: purification and localization on surfaces of spermatogenic cells and sperm. Journal of Cell Biology 108 367-375.

Alhadeff JA, Khunsook S, Choowongkomon K, Baney T, Heredia V, Tweedie A \& Bean B 1999 Characterization of human semen alpha-Lfucosidases. Molecular Human Reproduction 5 809-815.

Aviles M, Abascal I, Martinez-Menarguez JA, Castells MT, Skalaban SR, Ballesta J \& Alhadeff JA 1996 Immunocytochemical localization and biochemical characterization of a novel plasma membrane-associated, neutral $\mathrm{pH}$ optimum alpha-L-fucosidase from rat testis and epididymal spermatozoa. Biochemical Journal 318 821-831.

Benoff S 1997 Carbohydrates and fertilization: an overview. Molecular Human Reproduction 3 599-637.

Brandt Y, Lang A, Rodriguez-Martinez H, Madej A \& Einarsson S 2006 Impact of ACTH during oestrus on the ultrastructure of the spermatozoa and their environment in the tubal reservoir of the postovulatory sow. Animal Reproduction Science 93 231-245.

Buhi WC, Vallet JL \& Bazer FW 1989 De novo synthesis and release of polypeptides from cyclic and early pregnant porcine oviductal tissue in explant culture. Journal of Experimental Zoology 252 79-88.

Buhi WC, Alvarez IM \& Kouba AJ 2000 Secreted proteins of the oviduct. Cells, Tissues, Organs 166 165-179.

Calvete J, Ensslin M, Mburu J, Iborra A, Martinez P, Adermann K, Waberski D, Sanz L, Topfer-Petersen E, Weitze K-F et al. 1997 Monoclonal antibodies against boar sperm zona pellucida-binding protein AWN-1. Characterization of a continuous antigenic determinant and immunolocalization of awn epitopes in inseminated sows. Biology of Reproduction 57 735-742.

Carrasco LC, Coy P, Avilés M, Gadea J \& Romar R 2008 Glycosidase determination in bovine oviductal fluid at the follicular and luteal phases of the oestrous cycle. Reproduction, Fertility, and Development 20 808-817.

Cornwall GA, Tulsiani DR \& Orgebin-Crist MC 1991 Inhibition of the mouse sperm surface alpha-D-mannosidase inhibits sperm-egg binding in vitro. Biology of Reproduction 44 913-921.

Corrales JJ, Burgo RM, Galindo P, Munoz-Barroso I, Miralles JM \& Villar E 2002 Abnormal expression of acid glycosidases in seminal plasma and spermatozoa from infertile men with varicocele. Reproduction 123 411-417.

Dostalova Z, Calvete JJ, Sanz L \& Topfer-Petersen E 1995 Boar spermadhesin AWN-1. Oligosaccharide and zona pellucida binding characteristics. European Journal of Biochemistry 230 329-336.

Droba M, Droba B \& Bledniak D 2005 Acid glycosidases from hen oviduct and egg albumen. Comparative Biochemistry and Physiology. Part B, Biochemistry and Molecular Biology 142 391-397.

Ekhlasi-Hundrieser M, Gohr K, Wagner A, Tsolova M, Petrunkina A \& Topfer-Petersen E 2005 Spermadhesin AQN1 is a candidate receptor molecule involved in the formation of the oviductal sperm reservoir in the pig. Biology of Reproduction 73 536-545.

Engle CC, Dunn S, Food RD, Williams DJ, Foley CW \& Trout HF 1968 Amino acids in sow and rabbit oviduct fluids. Journal of Animal Science 271786. 
Fazeli A, Hage WJ, Cheng FP, Voorhout WF, Marks A, Bevers MM \& Colenbrander B 1997 Acrosome-intact boar spermatozoa initiate binding to the homologous zona pellucida in vitro. Biology of Reproduction $\mathbf{5 6}$ 430-438.

van Gestel RA, Brewis IA, Ashton PR, Brouwers JF \& Gadella BM 2007 Multiple proteins present in purified porcine sperm apical plasma membranes interact with the zona pellucida of the oocyte. Molecular Human Reproduction 13 445-454.

Hafez ESE \& Hafez B 2000 Folliculogenesis, egg maturation, and ovulation. In Reproduction in Farm Animals, 7th edn, pp 68-81. Eds LWilliams and Wilkins. Pennsylvania, USA: Blackwell Publishing.

Hunter RH 1988 Fallopian tube fluid: the physiological medium for fertilization and early embryonic development. In The Fallopian Tubes. Their Role in Fertility and Infertility, pp 30-52. New York: SpringerVerlag.

Hunter RH 2005 The Fallopian tubes in domestic mammals: how vital is their physiological activity? Reproduction, Nutrition, Development 45 281-290.

Ignotz GG, Cho MY \& Suarez SS 2007 Annexins are candidate oviductal receptors for bovine sperm surface proteins and thus may serve to hold bovine sperm in the oviductal reservoir. Biology of Reproduction 77 906-913.

Iritani A, Sato E \& Nishikawa Y 1974 Secretion rates and chemical composition of oviduct and uterine fluids in sows. Journal of Animal Science 39 582-588.

Kapur DK \& Gupta GS 1985 Immunological specificity of hexosaminidases from human seminal plasma. American Journal of Reproductive Immunology and Microbiology 7 39-43.

Kuno M, Yonezawa N, Amari S, Hayashi M, Ono Y, Kiss L, Sonohara K \& Nakano M 2000 The presence of a glycosyl phosphatidylinositolanchored alpha-mannosidase in boar sperm. IUBMB Life 49 485-489.

Lefebvre R, Lo MC \& Suarez SS 1997 Bovine sperm binding to oviductal epithelium involves fucose recognition. Biology of Reproduction $\mathbf{5 6}$ 1198-1204.

Matsumoto M, Hirata J, Hirohashi N \& Hoshi M 2002 Sperm-egg binding mediated by sperm alpha-L-fucosidase in the ascidian, Halocynthia roretzi. Zoological Science 19 43-48.

Miller DJ, Gong X \& Shur BD 1993 Sperm require beta- $N$-acetylglucosaminidase to penetrate through the egg zona pellucida. Development 118 1279-1289.

Nichol R, Hunter RH \& Cooke GM 1997 Oviduct fluid pH in intact and unilaterally ovariectomized pigs. Canadian Journal of Physiology and Pharmacology 75 1069-1074.

Ohshima T, Murray GJ, Swaim WD, Longenecker G, Quirk JM, Cardarelli CO, Sugimoto Y, Pastan I, Gottesman MM, Brady RO \& Kulkarni AB $1997 \alpha$-Galactosidase A deficient mice: a model of Fabry disease. PNAS $942540-2544$.

Pérez FA, Roma SM, Cabada MO \& Marini PE 2006 Sperm binding glycoprotein is differentially present surrounding the lumen of isthmus and ampulla of the pig's oviduct. Anatomy and Embryology 211 619-624.

Pizarro RA, de Courel HR, de Giraudo RH \& de Martinez NR 1984 Glycosidases in the rat uterus during the oestrus cycle. Acta Physiologica et Pharmacologica Latinoamericana 34 271-276.

Rath D, Töpfer-Petersen E, Michelmann H-W, Schwartz P, von Witzendorff D, Ebeling S, Ekhlasi-Hundrieser M, Piehler E, Petrunkina A \& Romar R 2006 Structural, biochemical and functional aspects of sperm-oocyte interactions in pigs. In Control of Pig Reproduction VII, 1 edn, pp 317-330. Eds CJ Ashworth \& RR Kraeling. Nottingham: Nottingham University Press.

Raychoudhury SS, Suarez SS \& Buhi WC 1993 Distribution of lectin binding sites in the oviducts of cycling and hormone-treated pigs. Journal of Experimental Zoology 265 659-668.

Roberts GP, Parker JM \& Symonds HW 1975 Proteins in the luminal fluid from the bovine oviduct. Journal of Reproduction and Fertility $\mathbf{4 5}$ 301-313.

Roberts GP, Parker JM \& Symonds HW 1976 Macromolecular components of genital tract fluids from the sheep. Journal of Reproduction and Fertility 48 99-107.

Rodriguez-Martinez H 2007 Role of the oviduct in sperm capacitation. Theriogenology 68 138-146.
Samollow PB, Ford AL \& VandeBerg JL 1990 Biochemical characteristics and subcellular localizations of rat liver neuraminidase isozymes: a paradox resolved. Biochemical Genetics 28 283-298.

Sant'ana FJ, Nascimento EF, Gimeno EJ \& Barbeito CG 2005 Cyclic related and pathological changes in the lectin-binding sites on the swine oviduct. Reproduction in Domestic Animals 40 40-45.

Skudlarek MD, Tulsiani DR, Nagdas SK \& Orgebin-Crist MC 1993 Beta-Dgalactosidase of rat spermatozoa: subcellular distribution, substrate specificity, and molecular changes during epididymal maturation. Biology of Reproduction 49 204-213.

Smith PK, Krohn RI, Hermanson GT, Mallia AK, Gartner FH, Provenzano MD, Fujimoto EK, Goeke NM, Olson BJ \& Klenk DC 1985 Measurement of protein using bicinchoninic acid. Analytical Biochemistry 150 76-85.

Spiessens C, D'Hooghe T, Wouters E, Meuleman C \& Vanderschueren D 1998 Alpha-glycosidase activity in seminal plasma: predictive value for outcome in intrauterine insemination and in vitro fertilization. Fertility and Sterility 69 735-739.

Taitzoglou IA, Kokoli AN \& Killian GJ 2007 Modifications of surface carbohydrates on bovine spermatozoa mediated by oviductal fluid: a flow cytometric study using lectins. International Journal of Andrology $\mathbf{3 0}$ 108-114.

Takada M, Yonezawa N, Yoshizawa M, Noguchi S, Hatanaka Y, Nagai T, Kikuchi K, Aoki H \& Nakano M 1994 pH-sensitive dissociation and association of beta- $\mathrm{N}$-acetylhexosaminidase from boar sperm acrosome. Biology of Reproduction $\mathbf{5 0}$ 860-868.

Talbot P, Shur BD \& Myles DG 2003 Cell adhesion and fertilization: steps in oocyte transport, sperm-zona pellucida interactions, and sperm-egg fusion. Biology of Reproduction 68 1-9.

Taylor U, Rath D, Zerbe H \& Schuberth H-J 2008 Interaction of intact porcine spermatozoa with epithelial cells and neutrophilic granulocytes during uterine pasaje. Reproduction in Domestic Animals 43 166-175.

Thall AD, Maly P \& Lowe JB 1995 Oocyte Gal alpha 1,3Gal epitopes implicated in sperm adhesion to the zona pellucida glycoprotein ZP3 are not required for fertilization in the mouse. Journal of Biological Chemistry $27021437-21440$.

Topfer-Petersen E, Friess AE, Nguyen H \& Schill WB 1985 Evidence for a fucose-binding protein in boar spermatozoa. Histochemistry 83 139-145.

Topper EK, Killian GJ, Way A, Engel B \& Woelders H 1999 Influence of capacitation and fluids from the male and female genital tract on the zona binding ability of bull spermatozoa. Journal of Reproduction and Fertility 115 175-183.

Tulsiani DR \& Touster O 1981 Thymus involution and inhibition of spleen growth accompanies streptozotocin-induced diabetes in rats; possible relationship of these changes to the elevated hydrolase levels in diabetic plasma. Archives of Biochemistry and Biophysics 208 59-68.

Tulsiani DR, Skudlarek MD \& Orgebin-Crist MC 1989 Novel alpha-Dmannosidase of rat sperm plasma membranes: characterization and potential role in sperm-egg interactions. Journal of Cell Biology 109 1257-1267.

Tulsiani DR, Skudlarek MD, Araki Y \& Orgebin-Crist MC 1995 Purification and characterization of two forms of beta-D-galactosidase from rat epididymal luminal fluid: evidence for their role in the modification of sperm plasma membrane glycoprotein(s). Biochemical Journal 305 $41-50$.

Tulsiani DR, Chayko CA, Orgebin-Crist MC \& Araki Y 1996 Temporal surge of glycosyltransferase activities in the genital tract of the hamster during the estrous cycle. Biology of Reproduction 54 1032-1037.

Velasquez JG, Canovas S, Barajas P, Marcos J, Jimenez-Movilla M, Gallego RG, Ballesta J, Aviles M \& Coy P 2007 Role of sialic acid in bovine sperm-zona pellucida binding. Molecular Reproduction and Development 74 617-628.

Venditti JJ, Donigan KA \& Bean BS 2007 Crypticity and functional distribution of the membrane associated alpha-L-fucosidase of human sperm. Molecular Reproduction and Development 74 758-766.

Wagner A, Ekhlasi-Hundrieser M, Hettel C, Petrunkina A, Waberski D, Nimtz M \& Topfer-Petersen E 2002 Carbohydrate-based interactions of oviductal sperm reservoir formation-studies in the pig. Molecular Reproduction and Development 61 249-257. 
Walter I \& Bavdek S 1997 Lectin binding patterns of porcine oviduct mucosa and endometrium during the oestrous cycle. Journal of Anatomy 190 299-307.

Wiseman DL, Henricks DM, Eberhardt DM \& Bridges WC 1992 Identification and content of insulin-like growth factors in porcine oviductal fluid. Biology of Reproduction 47 126-132.

Yonezawa N, Amari S, Takahashi K, Ikeda K, Imai FL, Kanai S, Kikuchi K \& Nakano M 2005 Participation of the nonreducing terminal betagalactosyl residues of the neutral $\mathrm{N}$-linked carbohydrate chains of porcine zona pellucida glycoproteins in sperm-egg binding. Molecular Reproduction and Development 70 222-227.

Yoshida K, Takahashi T, Nakame Y, Saito H \& Kihara K 1987 N-acetyl-betaD-glucosaminidase (NAG) activity in human semen: its relation to gamma-glutamyl transpeptidase (gamma-GTP) activity in seminal plasma and reproductive tissues, and relation between seminal mucoprotein concentration and seminal NAG, and gamma-GTP activities. Acta Urologica Japonica 33 1054-1059.

Received 22 May 2008

First decision 20 June 2008

Revised manuscript received 19 August 2008

Accepted 27 August 2008 